\title{
Front Matter: Volume 10060
}

, "Front Matter: Volume 10060," Proc. SPIE 10060, Optical Biopsy XV: Toward Real-Time Spectroscopic Imaging and Diagnosis, 1006001 (24 March 2017); doi: $10.1117 / 12.2276282$

SPIE. Event: SPIE BiOS, 2017, San Francisco, California, United States 


\title{
PROGRESS IN BIOMEDICAL OPTICS AND IMAGING
}

\section{Optical Biopsy XV: Toward \\ Real-Time Spectroscopic Imaging and Diagnosis}

\author{
Robert R. Alfano \\ Stavros G. Demos \\ Editors
}

31 January-1 February 2017

San Francisco, California, United States

Sponsored by

SPIE

Co-sponsored by

Andor (United States)

Corning Incorporated (United States)

Coherent Inc. (United States)

Energy Research Company (United States)

Intuitive Surgical (United States)

Hamamatsu Corporation (United States)

NKT Photonics A/S (Denmark)

PerkinElmer (United States)

Thorlabs (United States)

TOPTICA Photonics AG (Germany)

Published by

SPIE 
The papers in this volume were part of the technical conference cited on the cover and title page. Papers were selected and subject to review by the editors and conference program committee. Some conference presentations may not be available for publication. Additional papers and presentation recordings may be available online in the SPIE Digital Library at SPIEDigitallibrary.org.

The papers reflect the work and thoughts of the authors and are published herein as submitted. The publisher is not responsible for the validity of the information or for any outcomes resulting from reliance thereon.

Please use the following format to cite material from these proceedings:

Author(s), "Title of Paper," in Optical Biopsy XV: Toward Real-Time Spectroscopic Imaging and Diagnosis, edited by Robert R. Alfano, Stavros G. Demos, Proceedings of SPIE Vol. 10060 (SPIE, Bellingham, WA, 2017) Seven-digit Article CID Number.

ISSN: 1605-7422

ISSN: 2410-9045 (electronic)

ISBN: 9781510605619

ISBN: 9781510605626 (electronic)

Published by

SPIE

P.O. Box 10, Bellingham, Washington 98227-0010 USA

Telephone +1 3606763290 (Pacific Time) · Fax +1 3606471445

SPIE.org

Copyright @ 2017, Society of Photo-Optical Instrumentation Engineers.

Copying of material in this book for internal or personal use, or for the internal or personal use of specific clients, beyond the fair use provisions granted by the U.S. Copyright Law is authorized by SPIE subject to payment of copying fees. The Transactional Reporting Service base fee for this volume is $\$ 18.00$ per article (or portion thereof), which should be paid directly to the Copyright Clearance Center (CCC), 222 Rosewood Drive, Danvers, MA 01923. Payment may also be made electronically through CCC Online at copyright.com. Other copying for republication, resale, advertising or promotion, or any form of systematic or multiple reproduction of any material in this book is prohibited except with permission in writing from the publisher. The CCC fee code is $1605-7422 / 17 / \$ 18.00$.

Printed in the United States of America.

Publication of record for individual papers is online in the SPIE Digital Library.

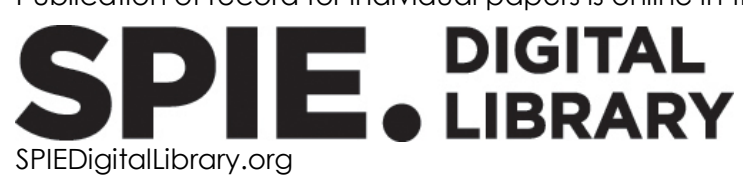

Paper Numbering: Proceedings of SPIE follow an e-First publication model. A unique citation identifier (CID) number is assigned to each article at the time of publication. Utilization of CIDs allows articles to be fully citable as soon as they are published online, and connects the same identifier to all online and print versions of the publication. SPIE uses a seven-digit CID article numbering system structured as follows:

- The first five digits correspond to the SPIE volume number.

- The last two digits indicate publication order within the volume using a Base 36 numbering

system employing both numerals and letters. These two-number sets start with 00, 01, 02, 03, 04, 05, 06, 07, 08, 09, OA, OB ... 0Z, followed by 10-1Z, 20-2Z, etc. The CID Number appears on each page of the manuscript. 


\title{
Contents
}

\author{
$\checkmark$ Authors \\ vii Conference Committee
}

OPTICAL BIOPSY: PATHWAY TO CLINICAL TRANSLATION I

1006002 The bedside diagnostic accuracy of a novice reflectance confocal microscopy reader for skin cancer detection in vivo in real-time: understanding challenges and potential pitfalls (Invited Paper) [10060-1]

1006004 Reflectance confocal microscopy-guided laser ablation of basal cell carcinomas: initial in vivo results (Invited Paper) [10060-3]

1006006 Performance of mid infrared spectroscopy in skin cancer cell type identification (Invited Paper) [10060-5]

\section{OPTICAL BIOPSY: PATHWAY TO CLINICAL TRANSLATION IV}

$10060 \mathrm{JJ} H y p e r s p e c t r a l$ imaging based on compressive sensing to determine cancer margins in human pancreatic tissue ex vivo [10060-18]

$10060 \mathrm{OL}$ Study of anti-cancer effects of chemotherapeutic agents and radiotherapy in breast cancer patients using fluorescence spectroscopy [10060-20]

\section{RAMAN AND LIGHT SCATTERING METHODS}

1006000 Raman spectroscopy for cancer detection and characterization in metastasis models (Invited Paper) [10060-22]

10060 OP An interactive visual interface for the determination of similarity patterns in the Fourier spatial frequency spectrum of laser speckle [10060-23]

\section{ADVANCED IMAGING METHODS}

10060 oY Fast hyper-spectral imaging of cytological samples in the mid-infrared wavelength region [10060-32]

1006010 Large area, label-free imaging of extracellular matrix using telecentricity [10060-34] 
1006015 Design of a modified endoscope illuminator for spectral imaging of colorectal tissues [10060-38]

1006016 In vivo measurement of the tissue oxygenation by time-resolved luminescence spectroscopy of protoporphyrin IX: strategies to minimize artefacts associated with photoproducts [10060-39]

1006017 Chemometric endogenous fluorescence for tissue diagnosis [10060-40]

1006018 Modulation of the endogenous production of protoporphyrin IX in a yeast-based model organism [10060-41]

1006019 Structured interferometry features in femtosecond supercontinuum: towards better understanding of supercontinuum for bio applications (Invited Paper) [10060-42]

\section{POSTER SESSION}

10060 1B Resonance Raman of BCC and normal skin [10060-44]

$100601 \mathrm{~A}$ Attenuated Total Reflection Fourier Transform Infrared (ATR-FTIR) in the discrimination of normal and oral cancer blood plasma [10060-45]

10060 1D Oral cancer detection based on fluorescence polarization of blood plasma at excitation wavelength $405 \mathrm{~nm}$ [10060-46]

$100601 \mathrm{E}$ Characterization and classification of oral tissues using excitation and emission matrix: a statistical modeling approach [10060-47]

10060 IF Quantification of hemoglobin and its derivatives in oral cancer diagnosis by diffuse reflectance spectroscopy [10060-48]

1006011 Synchrotron microCT imaging of soft tissue in juvenile zebrafish reveals retinotectal projections [10060-55] 


\section{Authors}

Numbers in the index correspond to the last two digits of the seven-digit citation identifier (CID) article numbering system used in Proceedings of SPIE. The first five digits reflect the volume number. Base 36 numbering is employed for the last two digits and indicates the order of articles within the volume. Numbers start with 00, 01, 02, 03, 04, 05, 06, 07, 08, 09, 0A, 0B...0Z, followed by 10-1Z, 20-2Z, etc.

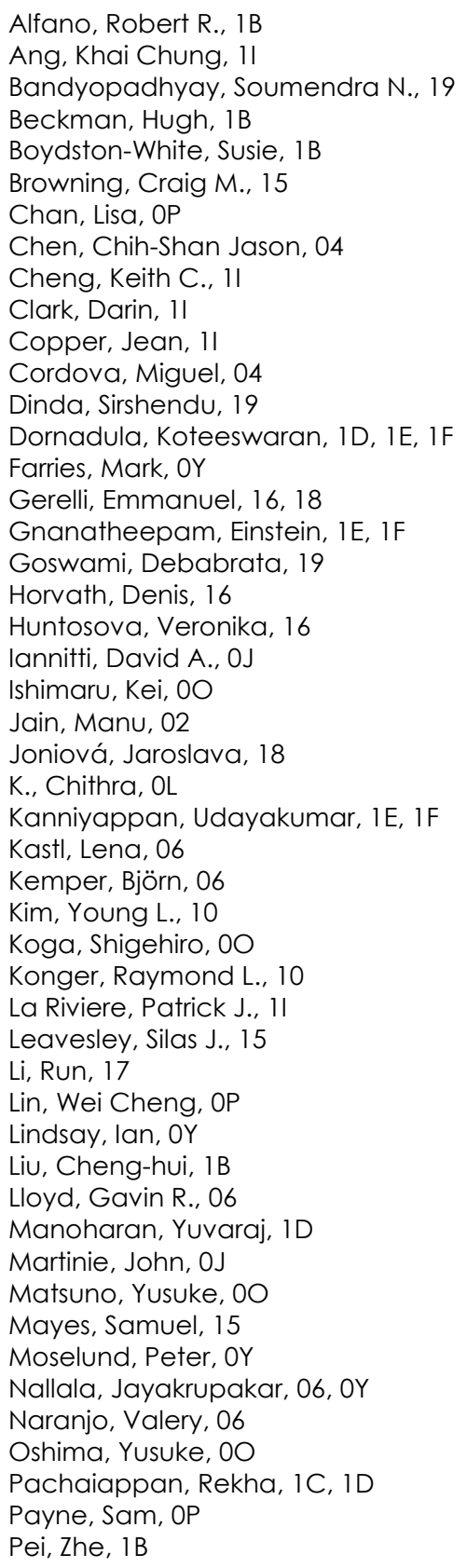


Proc. of SPIE Vol. $100601006001-6$

Downloaded From: https://www.spiedigitallibrary.org/conference-proceedings-of-spie on 26 Apr 2023 Terms of Use: https://www.spiedigitallibrary.org/terms-of-use 


\section{Conference Committee}

Symposium Chairs

James G. Fujimoto, Massachusetts Institute of Technology

(United States)

R. Rox Anderson, Wellman Center for Photomedicine, Massachusetts General Hospital (United States) and Harvard School of Medicine (United States)

Program Track Chairs

Tuan Vo Dinh, Fitzpatrick Institute for Photonics, Duke University (United States)

Anita Mahadevan-Jansen, Vanderbilt University (United States)

Conference Chairs

Robert R. Alfano, The City College of New York (United States) Stavros G. Demos, University of Rochester Laboratory for Laser Energetics (United States)

Conference Program Committee

Irving J. Bigio, Boston University (United States)

Nicole J. Crane, Naval Medical Research Center (United States)

Zhiwei Huang, National University of Singapore (Singapore)

Amir Gandjbakhche, National Institutes of Health (United States)

Israel Gannot, Johns Hopkins University (United States) and Tel Aviv University (Israel)

Igor V. Meglinski, University of Otago (New Zealand)

Yang Pu, The City College of New York (United States)

Lingyan Shi, Columbia University (United States)

Milind Rajadhyaksha, Memorial Sloan-Kettering Cancer Center (United States)

Angela B. Seddon, The University of Nottingham (United Kingdom)

Kestutis Sutkus, The City College of New York (United States)

Siavash Yazdanfar, GE Global Research (United States)

\section{Session Chairs}

1 Optical Biopsy: Pathway to Clinical Translation I

Yu Chen, University of Maryland, College Park (United States) 
2 Optical Biopsy: Pathway to Clinical Translation II

Nicusor V. Iftimia, Physical Sciences Inc. (United States)

3 Optical Biopsy: Pathway to Clinical Translation III

Milind Rajadhyaksha, Memorial Sloan-Kettering Cancer Center (United States)

4 Optical Biopsy: Pathway to Clinical Translation IV

Amir Gandjbakhche, National Institutes of Health (United States)

5 Raman and Light Scattering Methods

Lingyan Shi, Columbia University (United States)

Laura A. Sordillo, The City College of New York (United States)

6 Polarization Methods

Angela B. Seddon, The University of Nottingham (United Kingdom)

Yang Pu, The City College of New York (United States)

7 Advanced Imaging Methods

Alexander Doronin, Yale University (United States)

Igor Meglinski, University of Oulu (Finland)

8 Spectroscopy and Spectral Imaging Methods

Stavros G. Demos, University of Rochester Laboratory for Laser

Energetics (United States)

Lingyan Shi, Columbia University (United States) 